\title{
Breeding for Virus Resistance in Okra
}

\author{
Pradeep Kumar Jatav ${ }^{1 *}$, Kuldeep Singh ${ }^{2}$, Gruraj mathapati ${ }^{1}$, Rajashekhar Gowda ${ }^{1}$, \\ Sitaram karoriya ${ }^{3}$ and Manoj Kumar Nalla ${ }^{1}$
}

\author{
${ }^{1}$ Division of Vegetable Science, ${ }^{2}$ Division of Fruit and Horticultural Technology, Indian \\ Agricultural Research Institute, New Delhi, 110 012, India \\ ${ }^{3}$ Division of Entomology (RVSKVV, Gwalior), Madhya Pradesh, India
}

*Corresponding author

\section{A B S T R A C T}

Okra [Abelmoschus esculentus (L.) Moench], is an important crop which is widely

\section{Keywords}

YVMV, OELCV, Begomoviruses

Article Info

Accepted:

17 July 2018

Available Online:

10 August 2018 cultivated in different parts of the world mostly for human consumption and also for industrial use as fibre. The okra production in India, is hindered by occurrence viral diseases, like Yellow Vein Mosaic Virus (YVMV) disease and Okra Enation Leaf Curl Virus (OELCV) disease, spread by an insect vector, namely whitefly (Bemisia tabaci Gen), which affect okra production in terms of yield and fruit quality as well. The disease cannot control properly by using chemicals as concerned to environment and health issues, which remained us with practical option i.e., use of resistant/tolerant varieties for production. A huge research has been done in the direction of virus resistant variety development and to identify the different genetic source of resistance. In this review, the efforts have been made to expound the genetics of resistance to YVMV and OELCV in okra and also to provide complete information diversity of begomoviruses which affect the production of okra.

\section{Introduction}

Okra [Abelmoschus esculentus (L.) Moench], also called as bhendi or lady's finger belongs to the family Malvaceae is considered as an important vegetable crop of the tropical and subtropical regions of the world. It is popular in India, Pakistan, Nigeria, Cameroon, Iraq and Ghana. Though, it is virtually not grown in European countries, many people in these countries have now started eating this vegetable because of its nutritional composition with respect to vitamin $\mathrm{A}$, folic acid, carbohydrates, phosphorus, magnesium and potassium. It has been found an excellent source of iodine, which is very effective in controlling goiter. Its raw fruits if consumed on an empty stomach every morning nourish the body, cure ulcer and increase the semen content. The mucilaginous substance extracted from its roots and stems is used to clarify the sugarcane juice in jaggery manufacture. India ranks first in the world with an annual production of 6.36 million tonnes and a 
productivity of 11.9 tonnes/ha from an area of 0.53 million ha (Anonymous 2015).

The cultivated okra has somatic chromosome number $2 \mathrm{n}=130$ and is considered to be an amphidiploid of Abelmoschus tuberculatus $(2 n=58)$ and an unknown species with $2 n=72$ (Datta and Naug, 1968).Okra is a warm season crop, which thrives best during warm moist season, although grows fairly well in the hottest summer but growth and yield are found greater in rainy season as compared to springsummer. The optimum temperature for seed germination is $30^{\circ} \mathrm{C}$. The seeds fail to germinate below $19^{\circ} \mathrm{C}$. Cool climate reducesthe growth and productivity of okra, and considered as undesirable for its production. The ideal temperature for growing okra crop is $25-30^{\circ} \mathrm{C}$, when atmospheric temperature exceeds $42^{\circ} \mathrm{C}$ the flowers start dropping.

The crop is prone to damage by various biotic i.e., insects, fungi, nematodes viruses and biotic stress i.e., moisture stress, salinity, high and low temperature stress. Among them, viruses are poses serious constraint to okra production and the crop is susceptible to at least 19 different plant viruses (Swanson and Harrison 1993). These viruses severely affect okra production in terms of yield and fruit quality. Among them yellow vein mosaic disease (YVMD) and Okra Enation Leaf Curl Virus (OELCV), causes significant losses in the okra production. However, its cultivation in India is challenged by severe incidence of viral diseases, viz. Yellow Vein Mosaic Virus (YVMV) disease, Okra Enation Leaf Curl Virus (OELCV), yellow vein mosaic virus and leaf curl virus, spread by an insect vector, namely whitefly (Bemisia tabaci Gen).

\section{Yellow vein mosaic disease of okra}

In India, this disease was first identified by Kulkarni in 1924 and later on studied by
Capoor and Verma (1950) and Verma (1952) with implying that BYVMV might have originated in India. Further, Uppal et al., (1942) found the viral origin of the disease based on morphogenic symptoms expressed on plant and disease was named as yellow vein mosaic (YVM). Harrison et al., (1991) shown that this virus is a geminivirus based on its morphology and serological relation with African cassava mosaic virus. The yellow vein mosaic disease of okra is associated with another new recombinant virus namely okra yellow vein mosaic virus in Indian subcontinent. The nucleotide sequence identity between BYVMV and OYVMV-PK is $88 \%$ and the virus was recombinant with okra and cotton leaf curl virus, which is capable of infecting cotton and okra in epidemic proportions in Pakistan (Zhou et al., 1998). Whereas, BYVMV infects only okra in India. Hence, OYVMV is different from BYVMV infecting okra in Indian subcontinent.

Bhendi yellow vein mosaic viruses (BYVMV) belongsto the genus begomovirus in the family Geminiviridae. The genome of the virus is consisting of two similar sized DNA components (DNA A and DNA B). The DNA A component encodes a replication-associated protein (Rep) which is essential for viral DNA replication, a replication enhancer protein (REn), the coat protein (CP) and a transcription activator protein (TrAP) that controls late gene expression whereas, DNA B component encodes a nuclear shuttle protein (NSP) and a movement protein (MP), both of which are essential for systemic infection of plants (Gafni and Epel 2002). Most of the monopartite begomoviruses are associated with additional ssDNA molecules known as beta satellites (DNA1) (Briddon and Stanley 2006). Beta satellites associated with the monopartite viruses are approximately half the size of their helper begomoviruses and required to induce typical disease symptoms in 
their hosts (Venkataravanappa et al., 2011). These satellites depend on their helper virus for replication, movement, encapsidation and vector transmission. Alpha satellites are selfreplicating (Autonomous) circular ssDNA molecules, depend on the helper virus for movement, encapsidation and vector transmission and play no role in symptom induction (Briddon et al., 2004).

Begomoviruses have high recombination rate as their genomic size is small and the emergence of ' $\mathrm{B}$ ' biotype whiteflies is contributing to epidemics of begomoviruses in okra. The YVMV disease is characterized by development of homogenous interwoven network of yellow vein enclosing islands of green tissues within the leaf. In extreme cases, infected leaves become completely yellowish or creamy. If YVMV infection occurs within 20 days after germination of seedlings, their growth is retarded with few leaves and malformed fruits resulting in loss ranging from $94 \%$ to $100 \%$ depending upon growth stage of the plant (Sastry and Singh, 1974). The amount of damage declines with delay in infection the plants. A loss of $49-84 \%$ has been reported when infection occurred after 50-65 days of germination. Fruit yield is also greatly reduced, by as much as $96 \%$ if the crop is infected at early stage (Pun and Doraiswamy, 1999).

\section{Okra Enation Leaf Curl Virus (OELCV)}

Okra Enation Leaf Curl Virus (OELCV) disease is a serious problem in okra production in North India. The initial symptoms develop in form of small, pinheaded enations on leaves, leaf curling, and followed by warty and rough texture of the leaves. The lower surface of the leaves is characterized by mild, bold and prominent enations. There is twisting of main stem, lateral branches and leaf petiole. Leaf curling and enations are more prominent in middle- aged leaves. The leaves become thick and leathery. In advance stage of disease, there are enations, leaf thickening and curling even in the young leaves. At this time, the twisting and bending of the stem are so severe that the entire plant seems spreading on the soil surface. The infected plants either do not produce fruits or produce few deformed and small fruits unfit for marketing and consumption (Venkataravanappa et al., 2014). The yield loss varies from $30 \%$ to $100 \%$ depending upon the age of the plant at the time of infection (Sanwal et al., 2014).

\section{Diversity of begomovirus associated with yellow veinmosaic disease of okra}

Okra is susceptible to at least 19 different viruses throughout the world (Brunt et al., 1990, Swanson and Harrison 1993), which is major limiting factor for okra production throughout the world. The important viruses known to cause severe yield losses in okra are Okra mosaic virus a tymovirus (OkMV) from Ivoire, Nigeria, West Africa (Fauquet and Thouvenel 1987), Okra leaf curl virus from West Africa (Swanson and Harrison 1993), Okra yellow crinkle virus (OYCV) from Bamako, Mali (Shih et al., 2006) and Okra yellow mottle virus (OYMV) from Mexico.

Similarly in India, okra is susceptible to minimum 10 different viruses (Venkataravanappa, 2008), which are associated with YVDM becoming one of the major limiting factors in okra production. The begomovirus causes yellow vein mosaic disease in okra is monopartite and association of beta satellites is well characterized by Jose and Usha 2003, from Madurai district of Tamil Nadu, India. But recently, a detail survey throughout the country on begomoviruses associated disease of okra shown that minimum 9 different begomoviruses and 4 different type beta satellites are associated with the YVMD of 
okra in different combination under different agro-ecological zones.

The comparison of genome sequence with the selected begomovirus sequences revealed that it shared highest sequence identity of $96.1 \%$ with BYVMV (GU112057) and $89.7 \%$ with OYVMV-(AJ002451) infecting okra in India and Indian subcontinent (Venkataravanappa et al., 2014). This result was well supported by phylogenetic analysis with OYCHINT isolate closely clustering with BYVMV group. Based on current taxonomic criteria for begomovirus, the threshold cut off of nucleotide identity for species demarcation is $89 \%$ (Fauquet et al., 2008) and the virus isolates displaying more than this should be considered as strains rather than different virus species (Padidam et al., 1995). The present results indicate that OYCHINT is a new strain of Bhendi yellow vein mosaic virus from India infecting okra.

\section{Vector and favorable weather condition for YVMV}

These viruses are neither sap-transmissible nor seed-transmitted. The natural transmission is through whitefly in a semi-persistent manner. The minimum number of whiteflies required to induce $100 \%$ infection is 10/plant, although a single whitefly can transmit the YVMV effectively (Venkataravanappa et al., 2014).

The female whiteflies are more efficient than the male whiteflies in transmitting the virus (Venkataravanappa et al., 2014). Whitefly is one of the most important sucking pests that inflict heavy damage to the crop not only through direct loss of plant vitality by feeding on cell sap but also by transmitting yellow vein mosaic viruses. The emergence of new Bbiotype whitefly in south India was responsible for the epidemics of Tomato leaf curl virus in 1999 (Banks et al., 2001). The emergence of the polyphagous ' $\mathrm{B}$ ' biotype of $B$. tabaci with its increased host range of more than 600 plant species has resulted in Gemini viruses infecting previously unaffected crops. The ' $\mathrm{B}$ ' biotype has the capacity to transfer the viruses at a fast rate. Whiteflies population and severity of YVMD are largely influenced by weather conditions. The YVMD severity is pronounced in rainy season crops due to high temperature and humidity coupled with high level of vector population.

In north India, the crop sown in month of June, the pods reaching to marketable stage in month of July-August were least susceptible to YVMD $(4.1 \%)$ as compared to $92.3 \%$ infection when the crop was sown in month of July and maturing in the month of AugustSeptember (Roychaudhary et al., 1997). At Kalyani (West Bengal), the whitefly population dynamics was monitored throughout the seasons and it was observed that it was remarkably low during February to 1st fortnight of April and reached its peak in the month of August (Chattopadhyay et al., 2011).

\section{Disease control}

There are number of non-genetic measures to control the disease which includes use of disease free seeds, complete destruction of diseased plants, elimination of secondary host plants, adjustment of planting time to escape the attack of white fly, Heavy use of insecticides, that results in heavy use of insecticides results in increasing of cost of crop production, and also on other hand use of chemicals has limited success to control disease in high humid areas and is unsafe environment (Foolad et al., 2008).

Therefore, there is huge need for exploitation of genetic resistance by developing YVMV and OELCV resisting varieties through various conventional non-conventional breeding methods.

A number of institutes of the Indian Council 
of Agricultural Research (ICAR), State Agricultural Universities (SAUs) and private seed companies are working on various aspects of genetic improvement of okra in order to develop high yielding and diseaseresistant varieties. Through intensive research efforts more than 50 improved varieties and hybrids have been released. Some of these have already made significant impact/contribution in revolutionizing the production of okra in the country. However, a vast gap exists in the research efforts and the expected outcome. Emerging biotypes of whitefly, new virus strains and breakdown of resistance in okra varieties/ hybrids are the major challenges which need to be addressed.

\section{Mechanisms of Host Resistance}

The morphological, physiological and biochemical factors are found to be responsible for disease resistance. The morphological characteristic such as hairiness, color, thickness, toughness of tissue, etc. are found to be responsible for resistance, whereas, with respect to biochemical mechanism of host resist, there is maximum polyphenol oxidase activity, Peroxidase isozyme activity and lignin synthesis has been observed by Patel et al., (2017). Apart from this a multiple defense pathways such as salicylic acid (SA), ethylene and dependent pathways were also involved.

\section{Genetic sources of resistance}

Wild species of okra have stable and trustworthy sources of resistance to YVMD which include primarily A. manihot, $A$. angulosus, A. crinitus, A. tuberculatus, A. vitifolius, A. panduraeformis, A. pungens and A. tetraphyllus (Dhankar and Mishra, 2004; Singh et al., 2007). In these wild types accessions, there could be variation in level of resistance among various accessions within a species. However, the transfer of resistance from wild relatives has been hampered by sterility problems and was difficult to produce subsequent generations or even carry out backcrosses.

Besides wild species, many resistant lines are reported in the cultivated type's okra varieties including Pusa Sawani that was developed from an inter-varietal cross between IC-1542 (symptomless carrier for YVMD from West Bengal) and Pusa Makhmali, was the first example of resistant variety. Pusa Sawani showed field resistant to YVMD beside excellent agronomic performance. Sandhu et al., (1974) reported that an accession EC31830, Asuntem Koko from Ghana identified as Abelmoschus manihot (L) Medicus ssp. manihot was almost immune to YVMV which was utilized in the development of resistant varieties i.e., Punjab Padmini and Punjab 7.

The resistant varieties i.e., Arka Anamika and Arka Abhay were developed through interspecific hybridization between A.esculentus $\times$ A. tetraphyllus by IIHR. A. manihot ssp. manihot, A. manihot ssp. manihot var. Ghana and West African okra had symptomless carriers of YVMD and were useful in developing YVMD-resistant hybrids (Dhankar and Mishra 2004). Arora et al., (1992) evaluated 157 advanced germplasm and seven cultivars/ hybrids of okra for 2 years and they observed that Punjab Padmini and EMS-8 remained free from the YVMD. Okra varieties, Ok No. 6, LORM 1, VRO 3 and Punjab 7 were found free from this disease, whereas VRO 4 showed mild reaction (Batra and Singh 2000). Rashid et al., (2002) screened 12 germplasm accessions under field conditions and lines OK 292 and OK 285 showing resistance to YVMD were identified. Similarly 51 okra hybrids and their 20 parents Kranti and four hybrids were found to be highly resistant, P 7 was moderately resistant, while the rest of the parents and hybrids were susceptible or highly susceptible to YVMD 
(Dhankhar et al., 1996). Bora et al., (1992) graded five genotypes namely $\mathrm{Pb} 7, \mathrm{GOH} 6$, $\mathrm{GOH}$ 4, AROH 1, Pb 57 and 7411 as highly resistant to YVMD and recommended $\mathrm{GOH} 4$ and $\mathrm{GOH} 6$ directly for commercial cultivation. Abdul et al., (2004) found three accessions, IC 218887, IC 69286 and EC 305619 resistant and 43 lines moderately resistant to YVMD. Venkataravanappa et al., (2012c) screened 29 genotypes of okra (wild and cultivated species) under both artificial and natural conditions. None of the genotypes showed immunity to the disease. However, the genotypes Nun 1145 and Nun 1144 showed moderate resistance reactions under both glass house and field conditions.

\section{Genetics of resistance}

A variety of responses to YVMV were reported to occur in cultivated and wild species. many reports showed that YVMD resistance is controlled by two dominant complementary genes (Sharma and Sharma 1984a), on other hand many showed that there is a single dominant gene (Jambhale and Nerkar 1981) or two recessive genes (Singh et al., 1962) responsible governing the resistance against to YVMD. Dhankhar et al., (2005) concluded the hypothesis that two complementary dominant genes were involved in governing the resistance to yellow vein mosaic virus disease in okra. Earlier Ali et al., (2005) reported that tolerance to yellow vein mosaic virus in IPSA okra 1 is quantative, with possibly 2 major factors and dependent on gene dosage with incomplete dominant gene action. Further they observed that tolerance in IPSA okra 1 is genetic and not due to escape. But Vashisht et al., (2001) based on 9 generations derived from crosses involving resistant (Parbhani Kranti) and susceptible cultivars (Punjab 8, Punjab Padmini, Pusa Makhmali and Pusa Sawani) reported that additive gene effects were more significant than dominant gene effects.
Pullaiah et al., (1998) also suggested that resistance to yellow vein mosaic virus was controlled by two complementary dominant genes in susceptible $\times$ susceptible and susceptible $\times$ resistant cross combinations, while in resistant $\mathrm{x}$ resistant crosses two duplicate dominant genes were involved. Similarly in interspecific crosses between $A$. Manihot and A. tetraphyllus, a single dominant gene controlled theresistance (Dutta 1984) while Sharma and Dhillon (1983) reported that resistance to YVMD in $A$. manihot ssp. manihot was controlled by two dominant genes.

\section{Breeding approaches}

\section{Conventional methods}

Introduction

Selection

Mutation breeding

Hybridization

Inter specific hybridization

Pedigree method

Back cross breeding

\section{Non-conventional methods}

Identification of QTLs

Transgenic approach

RNAi silencing

\section{Screening for disease resistance}

The use of right screening technique to screen the resistant/tolerant genotype is crucial. A good screening technique is that which clearly discriminates between resistant and susceptible genotype. Sometime screening under natural condition may not be very liable, as disease escape and even absence of virus is very common. Hence, artificial screening techniques must be adopted. 
Yellow vein mosaic disease of okra

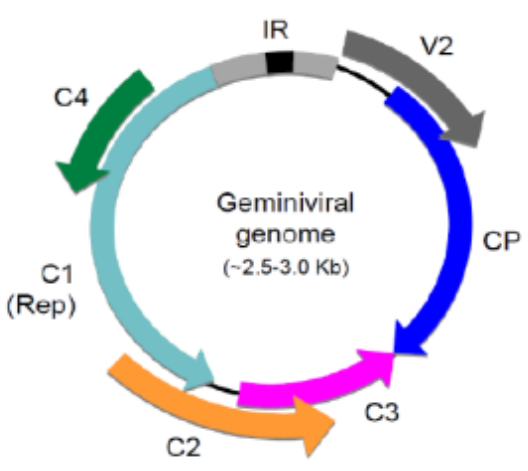

Monopartite

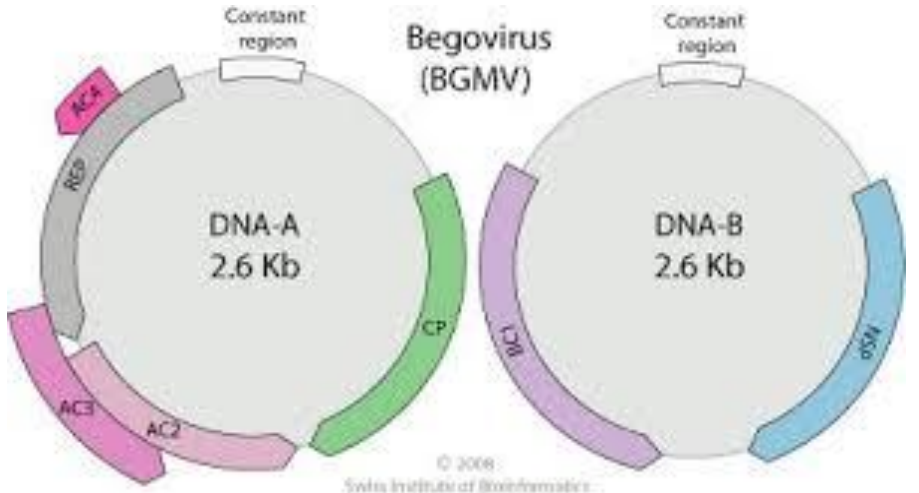

Bipartite

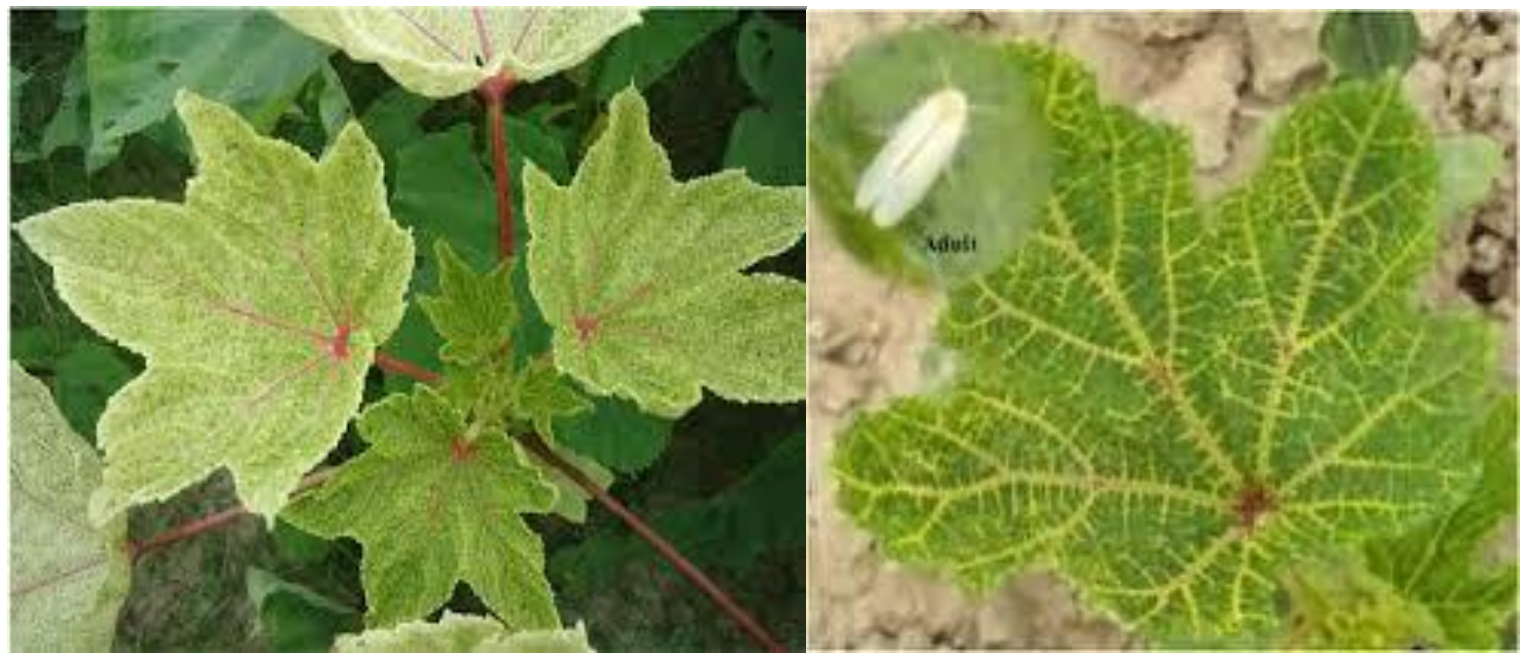

Okra Enation Leaf Curl Virus (OELCV)

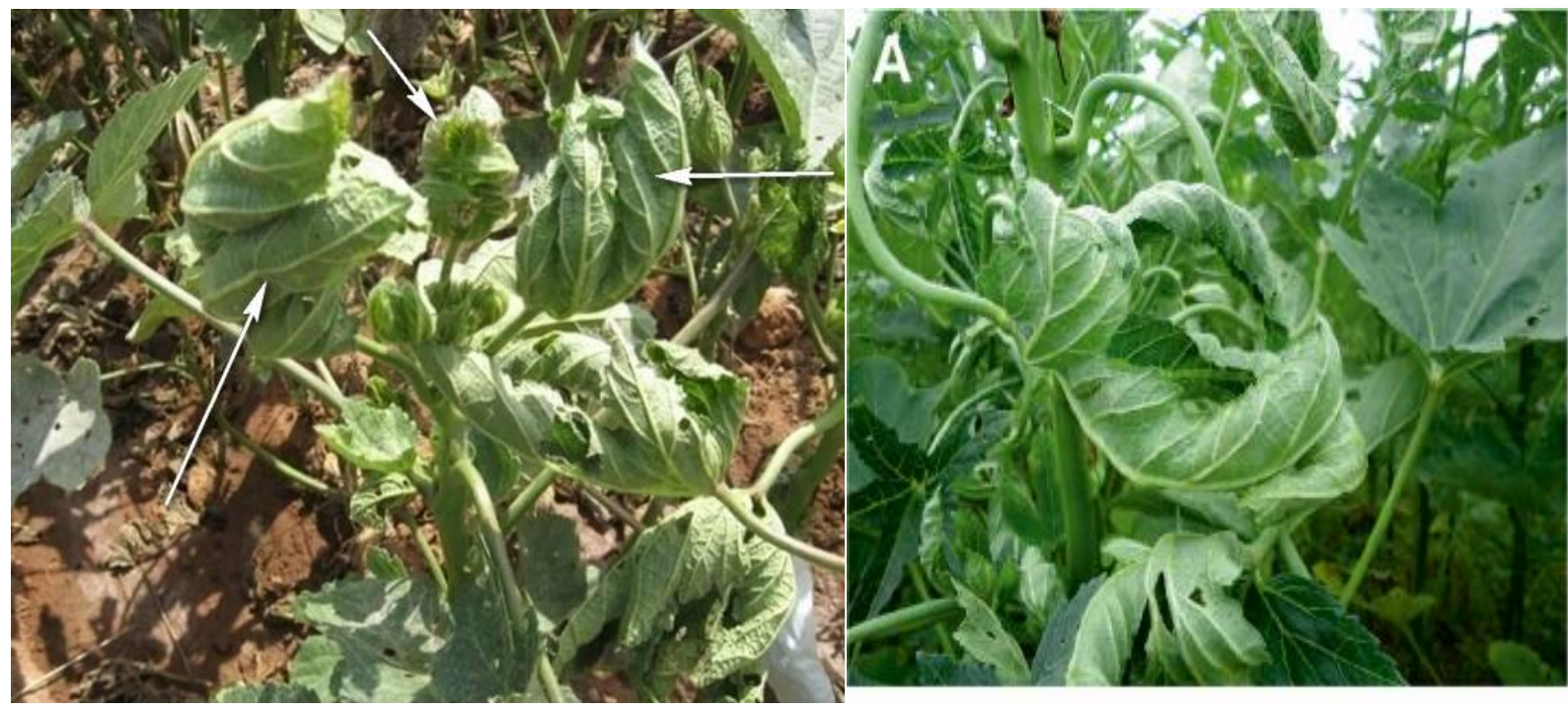


Diversity of begomovirus associated with yellow veinmosaic disease of okra

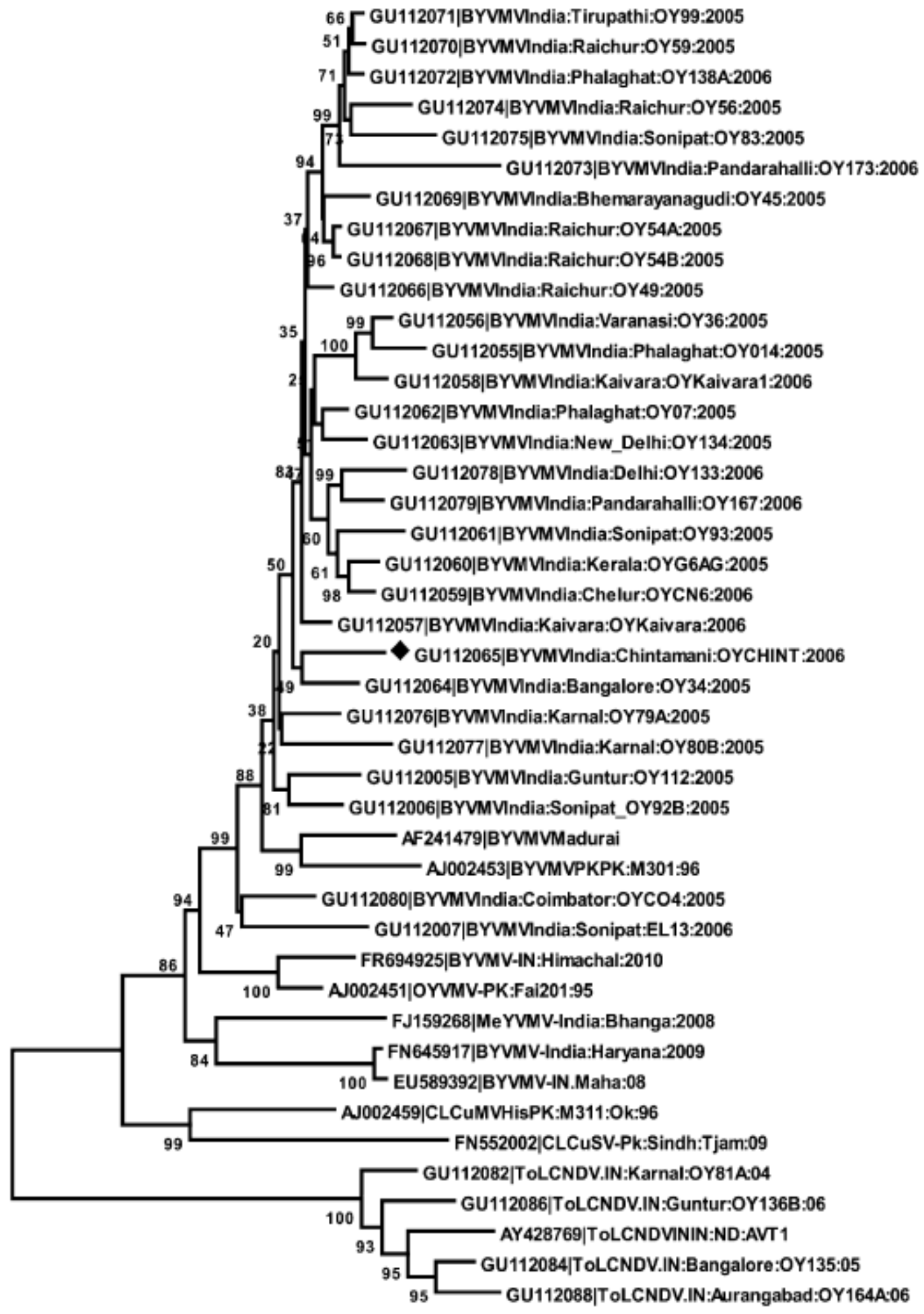




\section{Genetics of resistance}

\begin{tabular}{|l|}
\hline Resistance source \\
\hline Pusa Sawani (IC-1542XPusa \\
Makhmali) \\
\hline A. esculentus X A. manihot \\
ssp. Manihot \\
\hline A. manihot ssp. manihot X A. \\
esculentum cv 'Pusa Sawani' \\
\hline A. manihot X A. esculentum \\
cv 'Pusa Sawani' \\
\hline A. manihot sSp. Manihot \\
\hline A. manihot X A. tetraphyllus \\
\hline A. esculentus cv. Hisar Unnat \\
X A. manihot Spp. manihot \\
\hline
\end{tabular}

\begin{tabular}{l|l|}
\hline $\begin{array}{l}\text { Nature of resistance } \\
\text { Two recessive gene yv1/yv1, }\end{array}$ & Reference \\
$\begin{array}{l}\text { Two complimentary } \\
\text { dominant genes }\end{array}$ & Singh et al., 1962 \\
\hline $\begin{array}{l}\text { Single dominant gene } \\
\text { Single dominant gene }\end{array}$ & Jambhale and Nerkar, 1981 \\
\hline $\begin{array}{l}\text { Two dominant gene } \\
\text { Single dominant gene }\end{array}$ & Jambhale and Nerkar, 1981 \\
\hline $\begin{array}{l}\text { Two complimentary } \\
\text { dominant genes }\end{array}$ & Sharma and Dhillon, 1983 \\
\hline
\end{tabular}

Genotype classification

\begin{tabular}{|l|}
\hline S. no \\
\hline 1 \\
\hline 2 \\
\hline 3 \\
\hline 4 \\
\hline 5 \\
\hline 6 \\
\hline 7 \\
\hline
\end{tabular}

\section{Disease incidence $(\%)$}

0.0

$0-10$

$10-20$

$20-30$

$30-50$

$50-70$

More than 70

\section{Plant response}

Immune

Highly resistant (HR)

Resistant (R)

Moderately resistant (MR

50 Moderately susceptible (MS

70 Susceptible (S)

Highly susceptible (HS)

\section{Disadvantages of field screening}

Screening against particular virus is difficult

It may not possible to inoculate all the plants uniformly

It is not sure when virus will come

\section{Advantage artificial screening}

Screening against particular virus is possible

Inoculation of each and every plant can be done uniformly

Virus infection can be made at any stage of plant growth
Begomoviruses are spread through white fly. Therefore, this vector can be utilized to transmit the disease for screening purpose. The main objective of any disease screening programme, is to distinguish between resistant and susceptible genotypes. When resistance is governed by mono or oligo genes, the susceptible host would developed severe symptoms, whereas, resistant plants show no symptoms.

Hence, distribution of the resistance or susceptible response in segregating population, in this situation would be discontinuous and easy to identify. Whereas, resistance or susceptible response would be of continuous and difficult to identify, in segregation population if it is controlled by 
polygenes. Hence, in this case estimation of disease intensity through different techniques becomes very important.

\section{Assessment of resistance}

Disease incidence: It is defined as the portion of plants units infected, that is, percentage of diseased plants

Disease severity: It is defined as the portion of total area of plant tissue affected by disease

Measurement of number and size of successful infection

Disease incidence $=\stackrel{a}{a+----}$

Where,

a-number of diseased plants

b-number of healthy plants

The okra varieties/hybrid/line were classified based on disease response to YVMD under both artificial and natural conditions using criteria previously described by Borah et al., 1992.

\section{Biotechnological interventions}

The exploitation of biotechnological tools in okra breeding is often limited due to few molecular markers or no of molecular marker, genetic map or other molecular tools are available. No linkage map has been constructed so far in okra due large number of chromosomes (polyploidy) and larger genome size i.e., about $1600 \mathrm{mb}$. Reports on marker development in okra are very scanty and limited to characterization of cultivars. An agreement between clustering patterns obtained from morphological traits and molecular markers in Abelmoschus spp. has been demonstrated (Mortinello et al., 2001). Use of sequence related amplified polymorphism (SRAP) in marker aided selection (MAS) for various traits in Turkish germplasm was suggested (Gulsen et al., 2007). Ninety-three accessions of common (A. esculentus) and West African (A. caillei) okra could be distinguished using random amplified polymorphic DNA (RAPD) markers (Aladele et al., 2008). Sawadogo et al., 2009, analyzed 20 okra accessions from Burkina Faso using16 primers which designed to amplify SSR regionsof Medicago truncatula. Two accessions were found diverse from the other 18 , based on the presence of a distinctive $440 \mathrm{bp}$ fragment generated primer MT-27 and also on presence of hairs on fruits and delayed maturity of these two accessions.

Among viral diseases, YVMV and OELCV are being major disease causing huge economic loss in okra production; attempts are made for incorporation of specific genes such as $\mathrm{CP}$ (coat protein) gene and antisense RNA gene for elevated viral resistance.

\section{Future line of work}

Begomoviruses associated with ssDNA satellites pose a serious threat to okra production due to high diversity, recombination potential, limited knowledge of alternative hosts, and transmission by $B$. tabaci. Okra is susceptible to large number of begomoviruses which is probably due to its warm tropical climate supporting almost round the year survival of the whitefly vector, their overlapping host range, mixed cropping system and polyphagous nature of white fly. The screening of breeding populations is required to be done in specific regions in certain seasons as severity of YVMD.

Some studies have shown that the resistance is controlled by two dominant genes but 
others have reported that a single dominant gene is responsible for the resistance. There are also reports of duplicate and complimentary gene effects. Hence, extensive study is to be carried out in way to understand the genetics of resistance in donor parent that helps in choosing suitable breeding method. At the same time, attempts should also be made to incorporate broad spectrum resistance through gene pyramiding and develop okra varieties with durable resistance or tolerance to viruses.

The stable and reliable sources of resistant to viruses are found in wild species of okra but, the transfer of resistance from wild species is hampered by post zygotic sterility. So, systematic efforts must be made to overcome such barriers by screening in natural as well as under artificial conditions in laboratory.

The identification and validation of robust markers and development of linkage maps, and exploitation of these markers in screening of sources of resistance. The ploidy nature of okra is also to be considered while studying the breeding behaviour, inheritance and heritability of the characters as it is a natural/induced amphidiploids well known.

\section{References}

Abdul, N.M., Joseph, J.K. and Karuppaiyan, R., 2004. Evaluation of okra germplasm for fruit yield, quality and field resistance to yellow vein mosaic virus. Indian Journal of Plant Genetic Resources, 17: 241-4.

Ali, S., Khan, M.A., Habib, A., Rasheed, S. and Iftikhar, Y., 2005. Correlation of environmental conditions with okra yellow vein mosaic virus and Bemisia tabaci population density. International Journal of Agriculture and Biology, 7: 142-4.
Anonymous, 2015. Indian Horticulture Database. National Horticulture Board, Ministry of Agriculture, Government of India, Gurgaon.

Arora, S.K., Dhanju, K.C. and Sharma, B.R., 1992. Resistance in okra [Abelmoschus esculentus (L.) Moench] genotypes to yellow vein mosaic virus. Plant Disease Research, 7: 221-5.

Bora, G.C., Saikia, A.K. and Shadeque, A., 1992. Screening of okra genotypes for resistance to yellow vein mosaic virus disease. Indian Journal of Virology, 8: 55-7.

Borah, G. C., Saikia, A. K., Shadeque, A., 1992. Screening of okra genotypes for resistance to yellow vein mosaic virus disease. Indian J Virol, 8:55-57.

Briddon, R.W. and Stanley, J., 2006. Subviral agents associated with plant singlestranded DNA viruses. Virology, 344: 198-210.

Briddon, R.W., Bull, S.E., Amin, I., Mansoor, S., Bedford, I.D., Rishi, N., Siwatch, S.S., Zafar, M.Y., Abdel-Salam, A.M. and Markham, P.G., 2004. Diversity of DNA 1, a satellite-like molecule associated with monopartite begomovirus-DNA $\beta \quad$ complexes. Virology, 324: 462-74.

Brunt, A., Crabtree, K. and Gibbs, A., 1990. Viruses of tropical plants. CAB International, Wallingford.

Chattopadhyay, A. Dutta, S. and Shatterjee, S., 2011. Seed yield and quality of okra as influenced by sowing dates. African Journal of Biotechnology, 28: 5 461-7.

Dhankhar, B.S. and Mishra, J.P., 2004. Objectives of okra breeding. (In) Hybrid Vegetable Development, pp 195-209.

Dhankhar, S.K., Dhankhar, B.S. and Saharan, B.S., 1996. Screening of okra genotype for resistance to yellow vein mosaic disease. Annals of Biology, 12: 90-2.

Dhankhar, S.K., Dhankhar, B.S. and Yadava, R.K., 2005. Inheritance of resistance to 
yellow vein mosaic virus in an interspecific cross of okra (Abelmoschus esculentus). Indian Journal of Agricultural Sciences, 75: 87-9.

Dutta, O.P., 1984. Breeding okra for resistance to yellow vein mosaic virus and enation leaf curl virus. Annual Report, IIHR, Bangalore (India).

Fauquet, C. and Thouvenel, J.C., 1987. Okra leaf curl virus. (In) Plant Viral Diseases in the Ivory Coast, Paris, pp 96-7.

Gafni, Y. and Epel, B.L., 2002. The role of host and viral proteins in intra- and inter-cellular trafficking of geminiviruses. Physiology and Molecular Plant Pathology, 60: 231-41.

Harrison, B.D., Muniyappa, V., Swanson, M.M., Roberts, I.M. and Robinson, D.J., 1991. Recognition and differentiation of seven whiteflytransmitted geminiviruses from India and their relationships to African cassava mosaic and Thailand mungbean yellow mosaic viruses. Annals of Applied Biology, 118: 297-308.

Jambhale, N.D. and Nerkar, Y.S., 1981. Inheritance of resistance to okra yellow vein mosaic disease in interspecific crosses of Abelmoschus. Theoritical and Applied Genetics, 60: 313-6.

Jose, J. and Usha, R., 2003. Extraction of geminiviral DNA from a highly mucilaginous plant (Abelmoschus esculentus). Plant Molecular Biology Reporter, 18: 355.

Patel, J. S., Japda, A. R., hruve, J.J. and Patel, N.J., 2017. Antioxidant Enzymes in leaves of susceptible and resistant okra genotypes against YVMV. Int.J.Curr.Microbiol.App.Sci, $\quad$ 6(2): 1540-1550.

Pullaiah, N., Reddy, T.B., Moses, G.J., Reddy, B.M. and Reddy, D.R., 1998. Inheritance of resistance to yellow vein mosaic virus in okra [Abelmoschus esculentus (L.) Moench]. Indian
Journal of Genetics and Plant Breeding, 58(3): 349-52.

Rashid, M.H., Yasmin, L., Kibria, M.G., Mollik, A.K.M.S.R. and MonowarHossain, S.M., 2002. Screening of okra germplasm for resistance to yellow vein mosaic virus under field conditions. Plant Pathology journal, 1: 61-2.

Roychaudhary, J., Vethannayagam, S. M., Bhat, K. and Sinha, P., 1997. Management of yellow mosaic virus disease in bhindi (Abelmoschus esculentus) by sowing dates and with neem products. IPS Golden Jubilee International Conference, New Delhi, India, p 29.

Sandhu, G.S., Sharma, B.R., Singh, B. and Bhalla, J.S., 1974. Sources of resistance to jassids and white fly in okra germplasm. Crop Improvement, 1: 7781.

Sanwal, S. K., Singh, M., Singh, B., and Naik, P. S., 2014. Resistance to Yellow Vein Mosaic Virus and Okra Enation Leaf Curl Virus: challenges and future strategies. Current science, 11(106): 1470-1471.

Sharma, B.R. and Dhillon, T. S., 1983. Genetics of resistance to yellow vein mosaic virus in interspecific crosses of okra. Genetics Agraria, 37: 267-75.

Sharma, B.R. and Sharma, O.P., 1984b. Field evaluation of okra germplasm against yellow vein mosaicvirus. Punjab Horticulture Journal, 24: 131-3.

Shih, S.L, Green, S.K., Tsai, W.S., Lee, L.M. and Levasseur, V., 2006. First report of a distinct begomovirus associated with okra yellow crinkle disease in Mali. Vegetable Science 25: 54-6.

Singh, B., Rai, M., Kalloo, G., Satpathy, S. and Pandey, K.K., 2007. Wild taxa of okra (Abelmoschus species) reservoir of genes for resistance to biotic stresses. Acta Horticulture, 752: 323-8. 
Singh, H.B., Joshi, B.S., Khanna, P.P. and Gupta, P.S., 1962. Breeding for field resistance to yellow vein mosaic in bhindi. Indian Journal of Genetics, 22(2): 137-44.

Swanson, M.M. and Harrison, B. D., 1993. Serological relationships and epitope profiles of isolates of okra leaf curl geminivirus from Africa and the Middle East. Biochimie, 75: 707-11.

Swanson, M.M. and Harrison, B.D., 1993. Serological relationships and epitope profiles of isolates of okra leaf curl geminivirus from Africa and the Middle East. Biochimie, 75: 707-11.

Uppal, B.N., Varma, P.M. and Capoor, S.P., 1940. Yellow mosaic of Bhindi. Current Science, 9: 227-8.

Vashisht, V.K., Sharma, B.R. and Dhillon, G.S., 2001. Genetics of resistance to yellow vein mosaic virus in okra. Crop Improvement, 28(2): 18-25.

Venkataravanappa, V., 2008. Molecular characterization of bhendi yellow vein mosaic virus. Ph.D. thesis, GKVK, Bengalure

Venkataravanappa, V., Reddy, C.N.L. and Reddy, M.K., 2012c. Begomovirus characterization, and development of phenotypic and DNA-based diagnostics for screening of okra genotype resistance against bhendi yellow vein mosaic virus. Biotechnology. DOI 10.1007/s13205-012-0107-z.

Venkataravanappa, V., Reddy, C.N.L., Jalali, S., Briddon, R. W. and Reddy, M. K., 2014. Molecular identification and biological characterisation of a begomovirus associated with okra enation leaf curl disease in India. Eur. $J$. Plant Pathol, DOI 10.1007/s10658-0140463-0.

Venkataravanappa, V., Reddy, C.N.L., Swaranalatha, P., Jalali, S., Briddon, R.W. and Reddy, M.K., 2011. Diversity and phylogeography of begomovirusassociated beta satellites of okra in India. Virology Journal, 8: 555-60.

Zhou, X., Liu, Y., Robinson, D.J. and Harrison, B.D., 1998. Four variants among Pakistani isolates of cotton leaf curl virus and their affinities to DNA-A of geminivirus isolates from okra. Journal of General Virology, 79: 91523.

\section{How to cite this article:}

Pradeep Kumar Jatav, Kuldeep Singh, Gruraj mathapati, Rajashekhar Gowda, Sitaram karoriya and Manoj Kumar Nalla. 2018. Breeding for Virus Resistance in Okra. Int.J.Curr.Microbiol.App.Sci. 7(08): 3053-3065. doi: https://doi.org/10.20546/ijcmas.2018.708.325 